\title{
Online Learning Pros and Cons During Covid PANDEMics: A CASE Results of Students in a HIGHER EDUCATION INSTITUTION
}

\author{
MiliceVIC, J., SREMCEV, N. Cosic, I., RALEVIC, N. \& LAZAREVIC M.
}

Abstract: Online studies are becoming more common. Every year, the number of universities that offer online programs in addition to the traditional model increases. The global pandemic that has affected the whole world in recent months has imposed an urgent temporary reorganization of the educational system both in the world and in Serbia. The time and results of students' work in the coming period will show whether the online way of education (during the pandemic period) brought good results, but it is certainly time to change the education system. This research aims to point out the advantages and disadvantages of online learning, as well as its impact on student achievement, which was achieved by researching the number of applications, assessment of student turnout and taking subjects before and after isolation. The obtained results would indicate how the development of technology should be managed in the future in education systems, in order to reduce potential negative impacts to a minimum and in order to make education as high quality as possible.

Key words: Online education, the pandemic, student achivement, tehnology in education, professor support
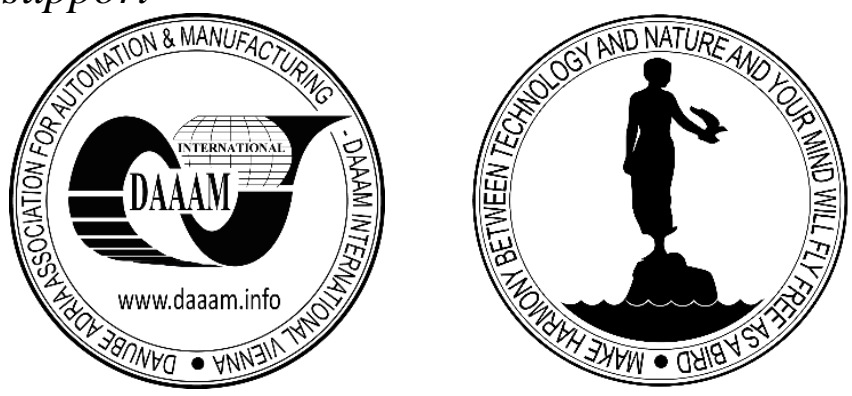

Authors' data: MSc. Milicevic J[elena], Assist. Prof. Sremcev N[emanja]; Univ. Prof. Cosic I[lija]; Univ. Prof. Ralevic N[ebojsa]; Univ. Prof. Lazarevic M[ilovan], University of Novi Sad, Faculty of Technical Sciences, Trg Dositeja Obradovica 6, Novi Sad, Serbia, jmilicevic1@gmail.com, nextesla@uns.ac.rs, ilijac@uns.ac.rs, nralevic@uns.ac.rs, laza@uns.ac.rs

This Publication has to be referred as: Milicevic, J[elena]; Sremcev, N[emanja]; Cosic, I[lija]; Ralevic, N[ebojsa] \& Lazarevic, M[ilovan] (2020). Online Learning Pros and Cons During Covid Pandemic: A Case Results Students in a Higher Education Institution, Chapter 12 in DAAAM International Scientific Book 2020, pp.151-170, B. Katalinic (Ed.), Published by DAAAM International, ISBN 978-3-902734-27-3, ISSN 1726-9687, Vienna, Austria

DOI: $10.2507 /$ daaam.scibook.2020.12 


\section{Introduction}

\subsection{The needed}

Throughout the world, as well as in our country, for many years there have been online classes, courses and the acquisition of knowledge in this way. The global pandemic that has affected the whole world in recent months has imposed an urgent temporary (or new) reorganization of the education system both in the world and in Serbia, but even before the COVID-19 virus pandemic began, the technology was adopted and its use was increased in education, especially remote online assessment (Tapper et al, 2020).

At one point, global investment in technology in education reached $\$ 18.66$ billion in 2019, while the e-learning market is projected to reach $\$ 350$ billion by 2025. Whether it is language applications, virtual teaching, video conferencing tools or online learning software, there has been a significant increase in usage especially since the COVID-19 virus pandemic began (Gov.rs, 2020).

Nevertheless, at one point during the pandemic it was a problem for many countries to completely replace the traditional way of education with a modern online way of education. The education system has been transferred to the online classroom, and with basic research methods, analysis and synthesis of the obtained information, we conclude that the data worldwide show one billion and five hundred million children and youths who temporarily did not go to schools, colleges and universities, as they had to follow the classes from home (Gov.rs, 2020).

The COVID-19 pandemic has significantly affected education, and there is a high potential that it will exacerbate pre-existing educational problems and inequalities in the region. In order to minimize the potential negative impacts, much more attention and resources need to be steered in that direction - and the countries of the Western Balkans have already started activities to mitigate the consequences of the crisis (Burzanovic, 2020).

\subsection{Issue}

Most countries, however, have not worked to improve the technology of online education alone by providing good platforms to support it (Stankovski et al., 2019). What is also one of the problems is the definition and interpretation of the term - what online teaching actually means. A number of professors have digitized their lectures and this is a good step towards improving the education system. However, one of the problems is taking the exams online, which requires changes in the law (in the case of the Republic of Serbia), which currently prescribes that the exam must be taken at the headquarters of the institution. Some foreign universities have introduced the possibility of online testing, where there is little time left for solving each question, so if the student does not answer within the set deadline, he or she moves on to the next one. Regardless of the good sides, the problem with online lectures is that you never know exactly who is listening 
to them and how many people are involved, if we are talking about students and pupils (Rts, 2020).

The data show that students, as well as professors in the period of the pandemic, face numerous challenges that need to be overcome, which certainly affected the success achieved in the months after the proclamation of the pandemic.

One of the main problems of most professors, looking at the period during the pandemic, but also later, is the adequate equipment (which includes laptops, cameras, projectors) that is necessary to have in order for the professor to conduct online classes in a quality way. Professors need excellent software to have the right conditions for their work, which was not the case with many of them. Also, it is very important to mention the appropriate platforms that require payment, that are not easily accessible, but which are necessary in terms of continuity of the session conducted by a particular professor.

For all these reasons, support is needed primarily for professors, because if we want to continue in some future period with online education, there must be state-of-the-art technology, trained teachers in this regard (they need to be provided with quality training), preparation for online classes, as well as technological equality, so that everyone can adapt to the conditions of electronic teaching. Also, every school institution, higher or lower, requires its own distance learning center, because that would make everything easier to function (Paunovic, 2020).

Another problem in online education, if we look at it from the point of view of students in the Western Balkans, is that they have more limited high-speed internet access than their peers in the European Union (EU), and regional data clearly indicate inequality (Nemet, 2019). On average, about 60 percent of households in the Western Balkans have access to the Internet at a speed that meets the prerequisites for e-learning (which is defined in the analysis as a speed of 10 or more Mbps). However, it should be noted that $10 \mathrm{Mbps}$ is lower than the standard considered acceptable in the US (25 Mbps) or the EU (30 Mbps). If these higher benchmarks are used, it can be seen that most households in the region do not have high speed internet connections (Burzanovic, 2020).

On average, one tenth of the households in the Western Balkans where students live do not have a computer; in Albania, this percentage climbs to almost a third, or 28 percent. Possession of information resources, however, differs significantly from the possibility of using them for educational purposes. Although an average of 86 percent of students claim that they have access to a computer that they can use for school, that percentage was probably lower in terms of restraint, when more householders claim these resources (for example, if parents have to work from home, or if computers must also be used for the educational needs of siblings). More importantly, the socio-economic gap in access to information resources was large. Almost all students in the highest quintile according to ESKS have access to the Internet, and a large number have 
a computer at home that they can use for school. However, as seen in Figure 1, these numbers are far lower among students in the lowest quintile (Burzanovic, 2020).

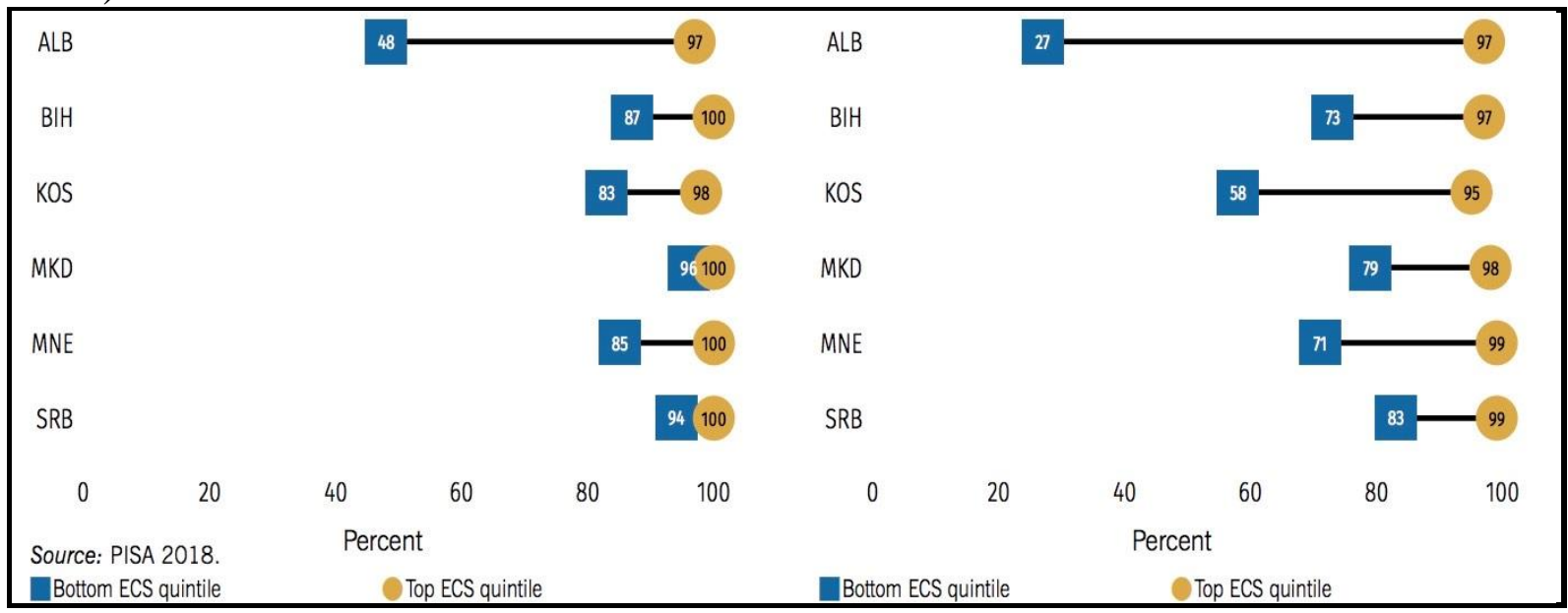

Fig. 1. Access to the Internet and ICT devices in the Western Balkans (left, internet access highest and lowest quintile per ESKS; right, a computer you can use for school highest and lowest quintile per ESKS; it can be seen that most households in the region do not have high-speed Internet connections (Burzanovic, 2020).

As mentioned before, some students do not have reliable access to the Internet and/or technology (Stankovski et al., 2016), and struggle to participate in digital learning, and this gap is observed among different countries, as well as between among economic strata within each country, which is the case in welldeveloped countries, not only in the Western Balkans. For example, while 95\% of students in Switzerland, Norway and Austria own and use a computer to create school assignments, according to the Organization for Economic Co-operation and Development (OECD), that percentage in Indonesia is only 34\%. In the United States, there is a significant gap between those from privileged and those from vulnerable backgrounds: while almost all 15-year-olds from privileged backgrounds said they own a computer they use for school, almost $25 \%$ of those from disadvantaged backgrounds did not. Although some schools and governments provide digital equipment to students in need, as is the case in New South Wales, Australia, many remain concerned that the pandemic will only deepen the digital division, as is the case in the Western Balkans, and our country, the Republic of Serbia (Gov.rs, 2020)

\subsection{The role of technology in education}

It is important to note that the purpose of technology is not to replace traditional education but to improve it when necessary, and also to provide a choice for those students who realized during the pandemic that online education is easier, simpler and more acceptable (Novak, 2020). In this way, much can be 
achieved and the costs of students and their parents can be reduced without compromising the quality of teaching.

Means of communication, such as e-mail and online discussion forums, allow students to express their views, and the interactivity of students with their colleagues, professors through chat rooms provides an approximately direct learning experience (ISerbia, 2020). All of this allows students to learn at their own pace through experimenting and following online educational platforms. In this way, better teaching methods can be developed over time (Novak, 2020).

\section{Research review}

\subsection{Methods}

In researching the impact of the current Covid-19 pandemic on the school system worldwide, this paper used information from various websites and institutions, as well as articles and journals. Also, in gathering information about how informational technology helped students follow their classes online during the pandemic and how online education has both advantages and disadvantages, sources that helped were official databases of scientific papers such as: science direct, emerald insight, kobson. Certainly research through Google academic helped to get information about the challenges faced by students from different language areas or from different countries during the pandemic, which led to drawing a conclusion whether online education in the long term may come as a support for the traditional way of education or can even be fully transferred to the online education system. The online search engine RefSeek made it possible to obtain information on various studies from journals and articles conducted around the world on the problem of education during the pandemic, which also point to the problems faced by the education system globally during the pandemic and how these problems are being solved, as well as what could be sustained as an example of good practice when it comes to education even after the pandemic crisis is over.

\subsection{The impact of the digital age on education during the Covid-19 pandemic in countries around the world}

The digital age could condition the change of books that are primarily digital, connecting people, new acquaintances, maybe it's time for great innovations in teaching, learning and research that will accompany primarily modern online classrooms.

COvid-19 forced many of the Chinese Universities to close their Campuses and switch their educational processes to online learning platforms. According to students' responses this way of teaching is a big challenge for them. Students showed lack of self-discipline, problems with adequate teaching material, or even with their own learning environment (Bao, 2020). 
Study in India, according to 70 teachers and 407 students' responses during Covid-19 pandemic concerning online classes showed that quality and time between students and professors, technical support, the way learning modules are structured are the core base of online learning. From teachers' perspective online classes are more convenient then classroom methods (46\% agree, 22.3\% disagree), Online classes are more effective then classroom mode (33\% agree, $54 \%$ disagree), there is a lack in teacher-student interaction (76\% agree, $10.5 \%$ disagree), Online classes are more fun (13\% agree, $72 \%$ disagree), technical issues effect the flow of teaching (90\% agree, 3\% disagree), Online classes helps teacher to use more innovative teaching methods (50\% agree, $25 \%$ disagree), online teaching boosted teachers' confidence ( $42 \%$ agree, $22.4 \%$ disagree), students do not take online classes seriously (76\% agree, $10.5 \%$ disagree), students make a lot of excuse for not attending an online class $(7.89 \%$ agree, $6.6 \%$ disagree), students show lack of interest in online classes (75\% agree, $13 \%$ disagree). From students' perspective online classes save time (59\% agree, 30\% disagree), quality of discussion is low (80\% agree, $10 \%$ disagree), technical issues disrupt the flow of learning ( $84 \%$ agree, $4.8 \%$ disagree), it is difficult to follow and understand online class (68.4\% agree, $16.3 \%$ disagree) (Nambiar, 2020).

Another study tried to answer how Ghanaian international students are satisfied with online learning platforms that have been organized at the educational institutions in Beijing, China. The purposive online survey has been used. The survey took 9 minutes to finish, included 315 students and 5-point Liker scale was used. Results showed that students are very satisfied with online learning, with a mean score of 3.77 , very satisfied with learning material with mean score of 3.72. Students identified some issues concerning online learning such as: it affects sense of togetherness in an environment, high cost of internet usage, and different time zones (Demuyakor, 2020).

One of the leading global educational networks Quacquarelli Symonds (QS) conduct a survey on how prospective international students and higher educational institutions are responding to Covid-19. Survey included 11.000 students and 400 university professionals. Study reveals that $57 \%$ of students plans to study abroad are impacted by Covid-19. Also $52 \%$ of students answered that they intend to defer their entry to next year. Some students have shown no interest in studying online (42\%), while others expressed positive interest (58\%), while $51 \%$ expected from their universities to switch their teaching lessons online (Quacquarelli, 2020).

Higher education policy institute (HEPI) published their findings on students' views and the impact of Corona virus on their educational experience. The survey took place on June, 2020 and included one thousand students from undergraduate levels. Only one out of five (19\%) students has shown that they have had great communication from their institutions. Majority of students (63\%) are satisfied with the way their institutions handled their remaining assessments, 
$42 \%$ of them are satisfied with online learning. Most of the students are expecting increased hygiene (75\%), 71\% expect online learning as well as social distancing (Hewit, 2020).

A Survey from India, which included 232 undergraduate and postgraduate students shows that $38 \%$ of them continued to learn from their textbox and elearning platforms, 54\% reported that they are spending less time for their learning. Only $14.1 \%$ are following their online classes daily, while $54 \%$ attends 3 days per week. Most of them are using mobile phones for their online learning classes (85.8\%) and $73.7 \%$ has never been using any platform before Covid-19. Majority of students 123 of them agreed that academic institution needs to be opened. Regarding stress, depression and anxiety, $42 \%$ of students agreed that they are facing some problems (Nanigopal at el., 2020). Regarding anxiety another study from China, including 3611 students, aged 18-24 confirms that students showed higher anxiety during Covid-19 (Wang \& Zhao, 2020).

In the UK, 440 students from 33 medical Universities were asked on how Covid-19 affects their final year exams, student assistantships and electives. The survey results are presented in Figure 2. As can be seen, 38.4\% of Objective Structured Clinical exams were cancelled, for written exams $55.9 \%$ reported no changes, whilst $26.8 \%$ had completed their exams online. Majority of medical elective placement were cancelled $(77.3 \%)$ due to travel restriction, $43 \%$ of students reported their assistantship was postponed. Almost $50 \%$ of students were asked to start working or assist in hospitals during Covid-19 (Choi at el., 2020).

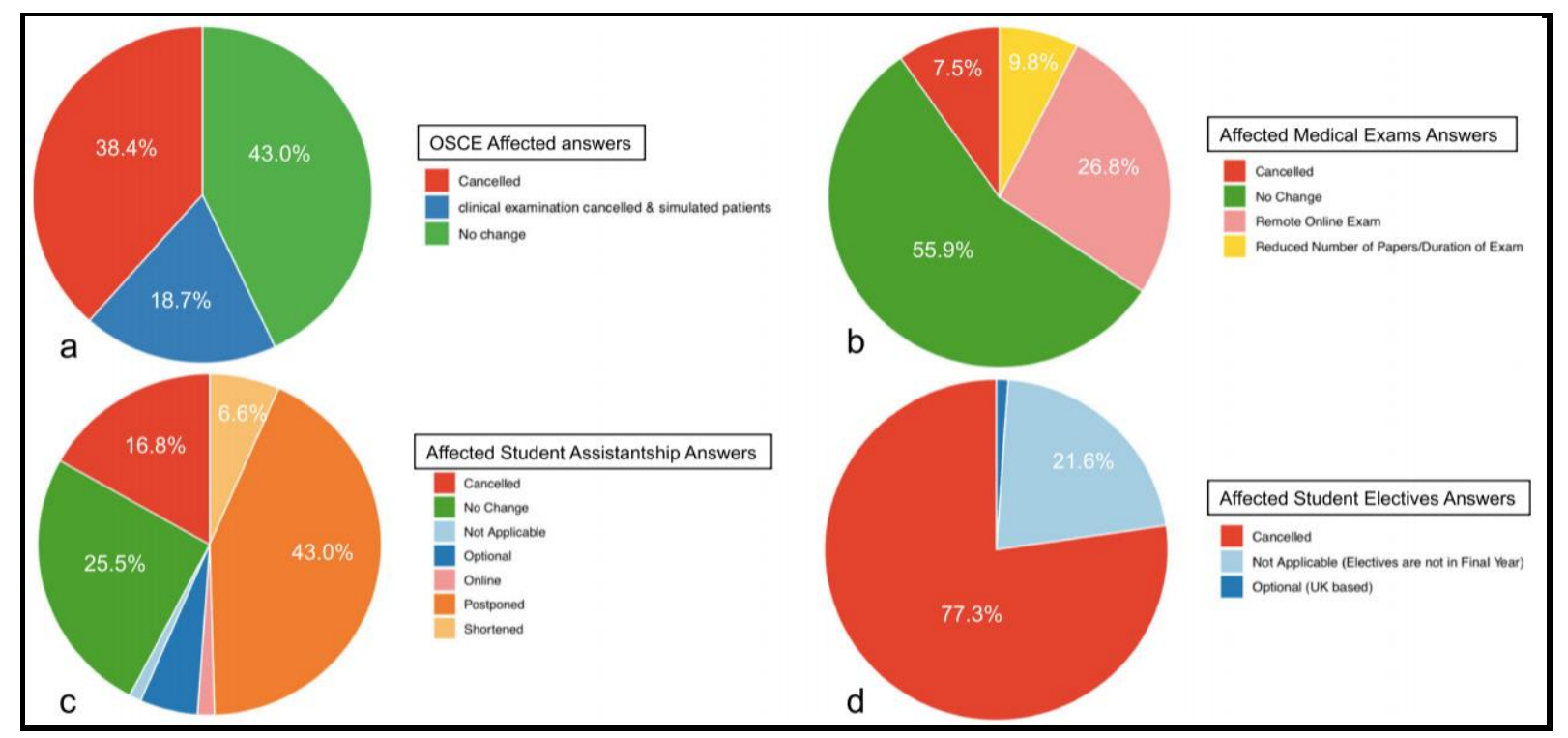

Fig. 2. The impact of covid-19 on medical schools OSCEs: (a) written exams, (b) assistantship, (c) and electives, (d) for (a-d), n=440 (Choi at el., 2020).

Study from Indonesian vocational high schools specialized in electrical engineering reaching 381 students, tried to explore the availability of educational institutions for online learning, ability to utilize those facilities and how distance 
learning is affecting students, is it more interesting or not comparing to traditional learning. Results shows that online learning is not more interesting than ordinary way of learning (approximately 84\% students agree online learning is not attractive to them), most of them can understand the lessons and they have a chance to participate during teaching process, $50 \%$ of students confirmed they have more assignments during online learning (Mulyanti at el., 2020).

Research taken at University of Dubai involving 133 students has shown that $55 \%$ of students are satisfied with distance learning during COvid-19. Among them $62 \%$ agreed online learning saves time and efforts to reach campuses, $60 \%$ have reported issues with understanding the class, because students are not involved so there is no direct conversation between student and professor (Saif almuraqab, 2020).

There are some difficulties felt in the implementation of the change process in the education system that has been arisen after COVID-19 crisis; these difficulties are related with the novel perspectives of online education and their technological complexities. Earlier to this pandemic, online education is considered as the education provided by the open universities, for example, in India. But in COVID-19 induced time, online teaching-learning became a massive challenge to deal with, and stakeholders are not potentially fit to adjust with the sudden educational change as they are not technologically competent to embrace the current situation. Therefore, for successful implementation of educational change (in this case, it refers to the shift from traditional teachinglearning methods to online teaching-learning methods), implications of change need to be addressed (Lokanath at el., 2020).

To get the findings of objective one, researchers conducted a survey study in which percentage analyses have been done to reveal the different types of online teaching-learning modes adopted by the teachers and students during the lockdown period. Table 1. portrays the details of the varied modes of online teaching-learning modes being used by the teachers and students during the lockdown period of COVID-19 outbreak. Mizoram University in India has developed its own Learning Management System in the wake of the suspension of the formal teaching-learning process due to the imposed lockdown by the government of India. All the teachers needed to log in on LMS and upload the study materials required by the students, clear their doubts on the discussion forum. So, it was one of the most popular means of digital education among teachers almost all the teachers reported in the Mizoram University but slightly down the percentage of 60 from students' side due to the accessibility reason of internet connectivity.

Interestingly, despite having a variety of digital modes of teachinglearning, almost all the teachers and students both were using WhatsApp/ Telegram and Email for educational interactions, submission of assignments, clarification of doubts and conducting class tests. There were $32 \%$ of teachers using Google classroom and 45\% teachers using Zoom/Cisco WebEx/Google 
Meet/Skype platform for taking online classes, but the recipient students were found only $20 \%$ and $15 \%$ respectively (Tab. 1). Twenty-five percent of teachers conducted Webinars as online teaching while 35\% of students were attended University's webinars and outside the University's webinars for enriching themselves widely as an online mode of learning. There were $50 \%$ of teachers recorded their lectures on YouTube as teaching through web mode, whereas 28\% of students watched presentations and recorded videos of all sources on YouTube (Lokanath at el., 2020).

\begin{tabular}{|c|l|c|c|}
\hline & \multicolumn{1}{|c|}{$\begin{array}{c}\text { S.N. Modes of online teaching- } \\
\text { learning modes }\end{array}$} & $\begin{array}{c}\text { \% of teachers using } \\
\text { online teaching } \\
\text { modes }\end{array}$ & $\begin{array}{c}\text { \% of students using } \\
\text { online learning } \\
\text { modes }\end{array}$ \\
\hline 1. & $\begin{array}{l}\text { Mizoram University-Learning } \\
\text { Management System (MZU-LMS) }\end{array}$ & 100 & 60 \\
\hline 2. & Google Classroom & 32 & 20 \\
\hline 3. & $\begin{array}{l}\text { Zoom/ Cisco WebEx/ Google Meet/ } \\
\text { Skype }\end{array}$ & 45 & 15 \\
\hline 4. & Webinar & 25 & 35 \\
\hline 5. & YouTube Videos & 50 & 28 \\
\hline 6. & YouTube/ Facebook Streaming & 6 & 18 \\
\hline 7. & WhatsApp/ Telegram & 87 & 100 \\
\hline 8. & Telephonic Conversation & 100 & 23 \\
\hline 9. & Email & 11 & 27 \\
\hline 10. & $\begin{array}{l}\text { Swayam Prabha educational DTH } \\
\text { channels/Zonet Cable TV }\end{array}$ & \\
\hline
\end{tabular}

Tab. 1. Showing different modes of online teaching modes used by the teachers and students (Lokanath at el., 2020).

YouTube and Facebook streaming as a means of virtual classes taken by the teachers found significantly very low with $6 \%$, whereas $18 \%$ of students admittedly found using these online platforms for learning. Eighty-seven percent of teachers were found using telephonic conversation for educationally get connected with their students in relation to giving and receiving information. Still, students tend to feel hesitant to call their teachers, and the percentage found only 23. Some teachers (34\%) showed an ardent interest in the pursuit of using the new technological tool of online teaching such as Swayam Prabha educational DTH channels/Zonet Cable TV with $11 \%$ only but students were found a little bit impressive 27\% using this digital tool for online learning (Lokanath at el., 2020).

2.3The impact of the digital age on education during the Covid-19 pandemic in the Western Balkans

Distance learning measures include a whole range of mechanisms for teaching: television and radio shows, resources posted on dedicated websites, online classes and communication with students via mobile phones, and teaching 
during the pandemic and the closure of schools and colleges involved a combination of several of the above methods. However, in order to enable, for example, the broadcasting of extensive television teaching material, both the material and the classes themselves were significantly shortened.

It is estimated that it will take months or even years to make up for the current closures of schools, faculties and in some way the loss of learning, which will require urgent measures to mitigate the impact of this problem, especially for students most severely affected by school closures. Average grades can be reduced in the short term, which is why some countries may return to the values that were last recorded in 2015 or even earlier (Burzanovic, 2020).

Many students may become functionally illiterate again after a pandemic. Assuming that the loss of learning is higher in students with lower grades, the average number of students with below-average achievement in reading literacy may increase from the current 53 percent to 61 percent after a pandemic (Fig. 3.). For example, during 2014, schools in Thailand were closed for a maximum of one month due to severe flooding, as a result of which student scores, depending on the subject and level, dropped by between 7 and 25 percent (Burzanovic, 2020).

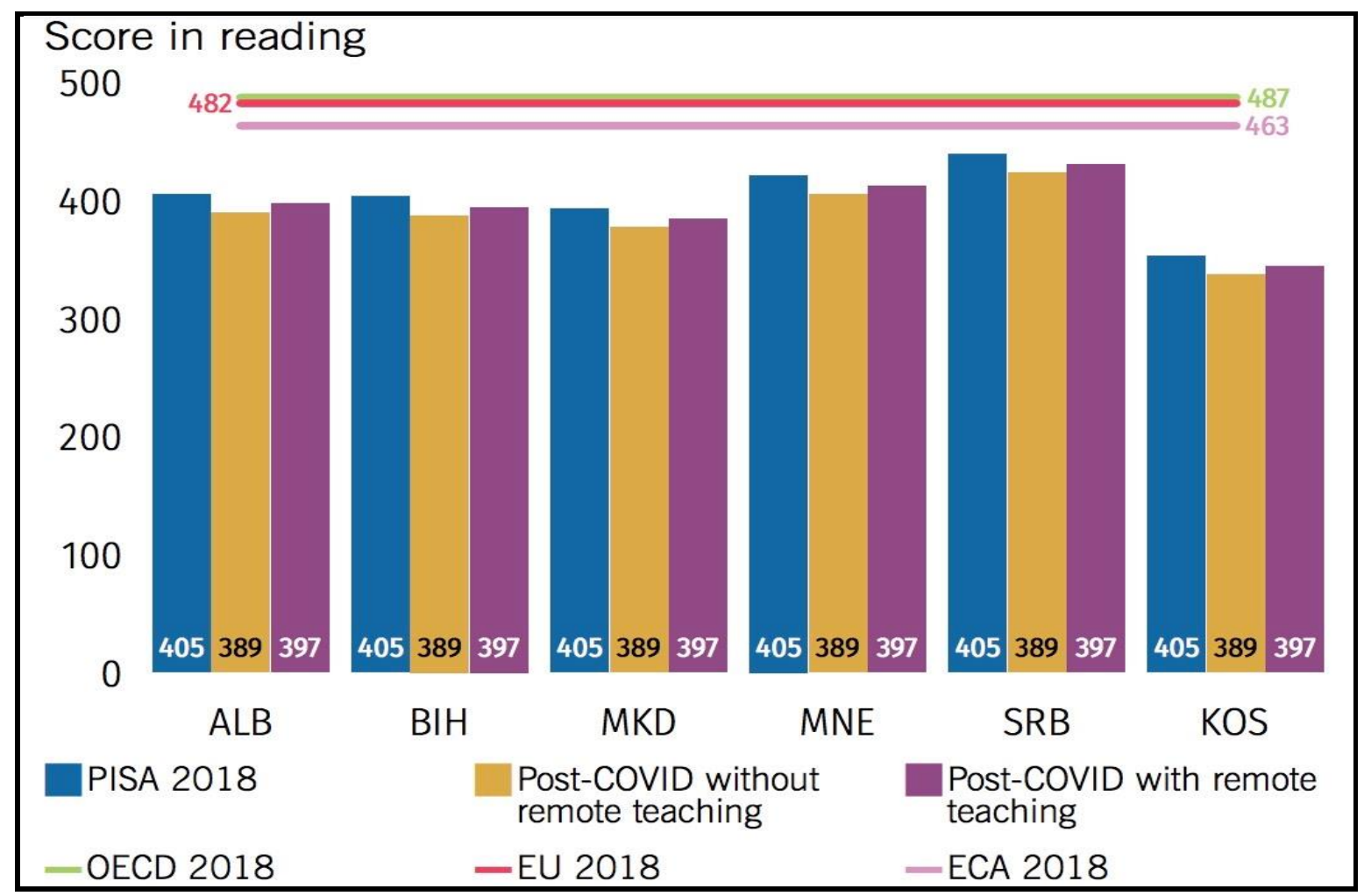

Fig. 3. Assessment of the impact of COVID-19 on PISA test scores (PISA data for 2018 and the World Bank staff budget; PISA - Organization for Economic Co-operation and Development (OECD) has been conducting the PISA test since 2000 every three years with with the aim of collecting international data on the quality, efficiency and equity of a country's education systems) (Burzanovic, 2020). 
Widespread unemployment and loss of income due to COVID-19 will seriously test the ability of households to pay for school expenses. Due to reduced household budgets, the poorest households may choose not to send their children to school even after they reopen. All school-related risk factors are particularly pronounced in the current situation where students attend distance learning for weeks and months outside the typical school environment, which creates additional pressure on the situation at home, especially in vulnerable households.

It will take several months or even years to make up for the past months of school closure and its consequences in the form of loss of learning, which will require urgent action to mitigate the impact of this problem. If this is not done, the level of human capital is likely to decline in the medium term, while economic opportunities for citizens will decline in the long run (Burzanovic, 2020).

\subsection{The impact of the digital age on education during the Covid-19 pandemic in the Republic of Serbia}

The digital age could condition the change of books that are primarily digital, connecting people, new acquaintances - maybe it's time for great innovations in teaching, learning and research that will accompany primarily modern online classrooms.

Due to the new model of education that was applied in Serbia during the current covid19 pandemic, but also in the world, platforms will be increasingly necessary for all those students who decide to learn through online teaching. In the upcoming period, this would require the most modern technology, a clear definition of the concept of online teaching, trained teaching staff, and the preparation of teaching to be conducted online, but also technological equality for all those who participate in teaching as students and teachers to adapt to the conditions of electronic teaching.

Although comparative data are not available, there are clear indications that in terms of digital skills, teachers in the Western Balkans are not ready to provide long-term support for effective distance or online learning. All Western Balkan countries recognize the importance of digital skills, although they apply different approaches in building those skills. For example, in Serbia there is a special curriculum for the development of digital competencies of teachers, and their ability to use digital technologies for student assessment is checked. Digital competences are part of the general competences of teachers in Montenegro and Northern Macedonia, although this is not the case in Albania and Bosnia and Herzegovina. Even in the EU, where digital teaching aids are more prevalent in schools than in the Western Balkans, only between 20 and 25 per cent of students are taught by teachers who master the technology. Prior to the outbreak of the global pandemic, the education systems of the Western Balkans were already facing serious challenges. None of them fully provided students with the skills needed in the labor market (Burzanovic, 2020). 
The analysis of PISA grades (Fig. 4.) for 2018 by country shows that on average 53 percent of students do not acquire the basic skills needed to function adequately in real life and work, in the modern workforce, compared to 23 percent in OECD countries.

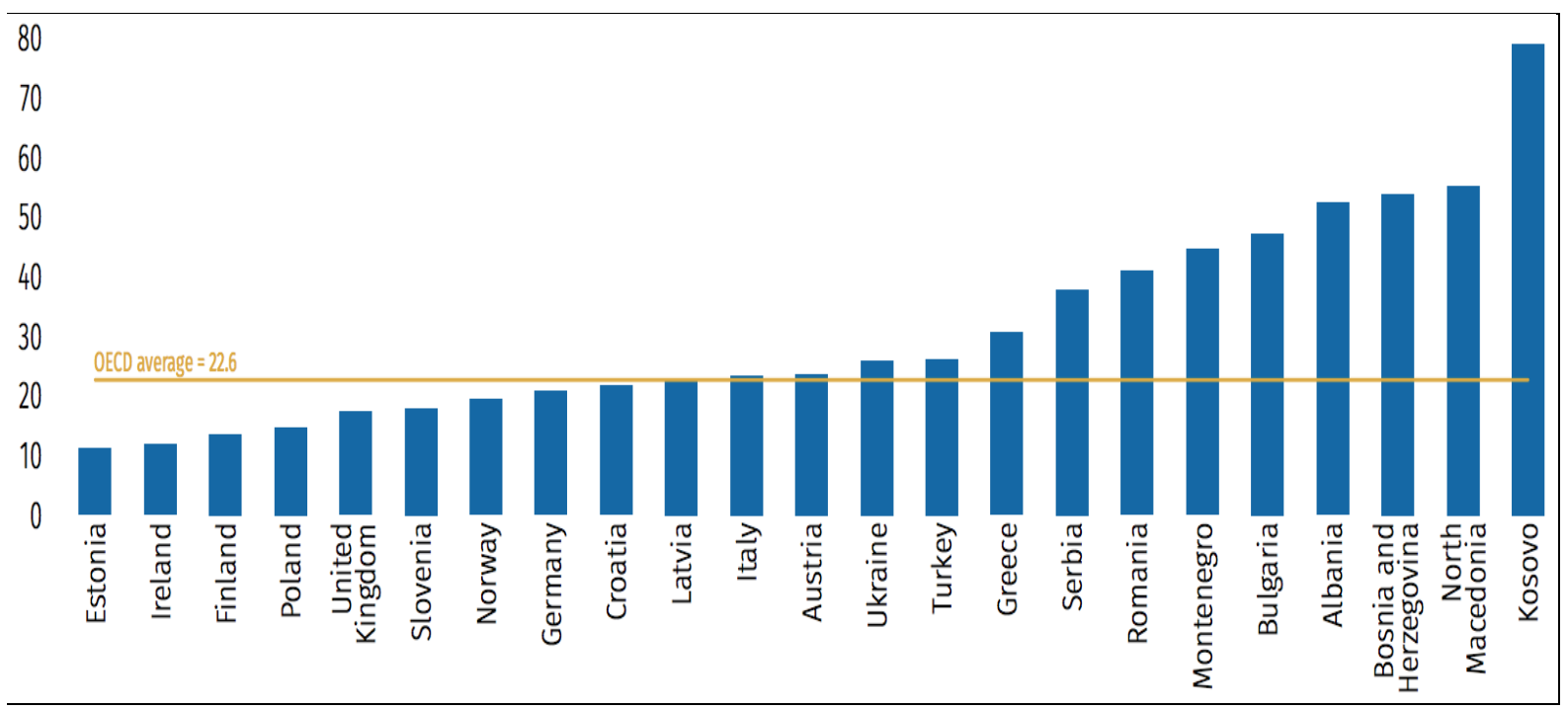

Fig. 4. Percentage of students with grades below the minimum literacy level, PISA 2018 (Burzanovic, 2020).

In Kosovo, over 78 percent of the population over the age of 15 is functionally illiterate, and that number is over 50 percent in Albania, Northern Macedonia and Montenegro (with below-level literacy scores according to PISA criteria).

Even in Serbia, which achieves the best results in the Western Balkans, 38 percent of students are functionally illiterate. In addition, inequalities in learning outcomes by gender, place of residence and income group are constantly present. Lack of achievement in terms of basic cognitive skills makes it difficult to acquire the higher-order skills needed to succeed in a rapidly changing knowledge economy (Burzanovic, 2020).

The research through the Internet came to the results of a survey conducted among students by the site NajStudent.com (Fig. 5.) during the state of emergency, which showed (in general) that students in Serbia were still not very satisfied with distance learning. 


\section{Research in Serbia - NajStudent.com}

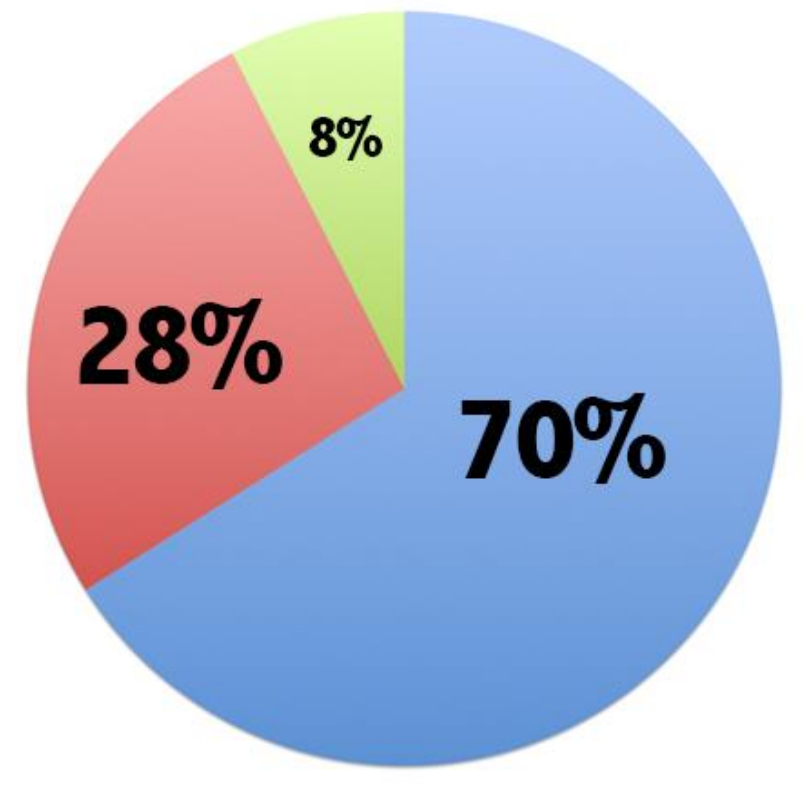

- $70 \%$ these changes had a bad effect on their acquisition of knowledge

$28 \%$ do not feel that there are big differences compared to regular lectures

$8 \%$ acquire knowledge more easily in this way

Fig. 5. Research trough the internet by site NajStudent.com.

The majority of students, as many as 70 percent, believe that these changes had a bad effect on their acquisition of knowledge, almost a quarter do not feel that there are big differences compared to regular lectures, while only eight percent stated that they acquire knowledge more easily in this way. Students rated their satisfaction with the implemented measures at higher education institutions due to the introduction of the state of emergency with an average grade of 3.19 (on a scale of 1 to 5). When they were asked about what faculties and colleges should do in these conditions, almost two-fifths of the students stated that they believe that they should make professors more accessible, and the same percentage said that the information on the website of these institutions needs to be more accessible. As many as 73 percent of respondents believe that the state of emergency will have a negative impact on enrollment in the next year of study, while 22 percent say that the impact will not be felt (Danas, 2020). Only five percent of them think that the consequences will be positive. All this implies that a lot of time is still needed to pass in order for an exclusively online education system to enable a high quality of education.

Due to the new model of education that was applied in Serbia during the current Covid-19 pandemic, but also in the world, platforms will be increasingly necessary for all those students who decide to learn through online teaching. In the coming period, this would require the most modern technology, a clear definition of the concept of online teaching, trained teaching staff, and the preparation of teaching that will be conducted online, but also technological 
Milicevic, J.; Sremcev, N.; Cosic, I.; Ralevic, N. \& Lazarevic, M.: Online Lea...

equality for all those who participate in teaching as students and teachers so that everyone can adapt to the conditions of electronic teaching.

\section{Discussion - Education in the future}

Numerous world universities are considering what the future of higher education will be in the coming period. As predicted by the World Innovation Summit for Education, the education systems in the world could undergo significant changes by 2030, and it is predicted that schools will become interactive environments in which innovations in technology and curricula will fundamentally transform the role of the teacher and change the way of learning itself (NG, 2020). The British University of Cambridge has decided to work online for the next academic year as well.

At the University of Belgrade, there are currently no concrete decisions on changes in the way of studying since October and focusing on online teaching, which will depend on the further development of the pandemic. What is certain, judging by the comments of both professors and students, is that online teaching in the previous period proved to be a very good form of teaching, but mostly for smaller groups of students, because students in this way participated in teaching more than usual, in the sense that they asked questions and that there was greater interaction with teachers in certain programs. Professors used a variety of platforms, from those designed for video conferencing to real distance learning platforms, and many colleges used both methods. Both professors and students have learned a lot in the previous period, combining online with traditional learning, and even after the end of the pandemic and emergencies, the so-called hybrid models of education could continue to be used so that in addition to classical lectures online teaching has a share, especially in programs with a small number of students, which in the near future could open the door to the digitalization of the teaching process in the Republic of Serbia, following the example of many foreign universities.

What is certain, judging by the comments of both professors and students, is that online teaching in the previous period proved to be a good form of teaching, but mostly for smaller groups of students, because students in this way more than usual participated in teaching, in the sense that they asked questions and that there was greater interaction with teachers in certain programs. Professors used a variety of platforms, from those designed for video conferencing to real distance learning platforms, and many colleges used both. Both professors and students learned a lot in the previous period, combining online with traditional learning, and even after the end of the pandemic and emergencies, the so-called hybrid models of education could continue to be used so that in addition to classical lectures online teaching certainly has a share, especially in programs with a small number of students, which in the near future could open the door to the 
digitalization of the teaching process in the Republic of Serbia, following the example of world universities.

However, it is obvious from the results of the survey, the registration of exams and exams passed at FTS (Faculty of Technical Sciences) in the previous period that students need some kind of encouragement and support when it comes to distance learning, or support to make up for what they have somehow lost during the pandemic in the times when the faculty had the option of exclusively online lectures, and is it necessary for them to be actively involved in all the contents provided by the faculty and to start actively combining both traditional and modern ways of learning and acquiring knowledge and adapting to new circumstances that seek to permanently change education, globally not only at the FTS level.

The conducted analysis included 30 subjects in 8 examination periods ( 3 examination periods before the covid19 pandemic and 5 examination periods after online classes) in which, depending on the examination period, from 400 (in March) to 1000 students applied (as many as in January). It was noticed that the percentage of students taking the registered exams did not change (about 70\%) even in the months after online classes, and that the success of students in the exams remained unchanged (Fig. 6).

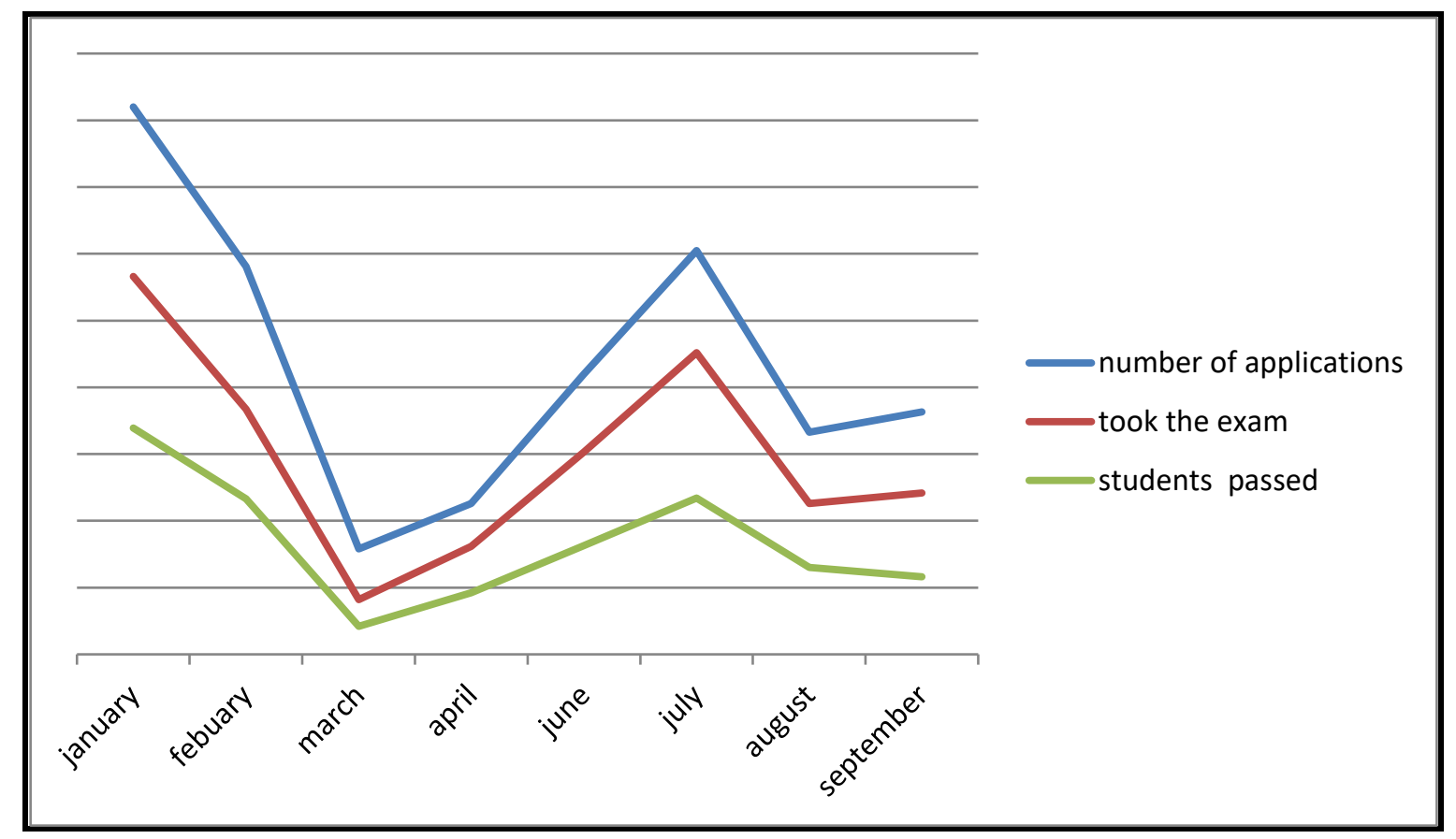

Fig. 6. Trend of taking exams before and after online classes

Also, it was noticed that the number of applications in later examination periods was lower, but this is normal every year because a number of students have already passed the exam in earlier examination periods, and the number of exams that students can apply for is limited to comply with measures taken by the authorities during the pandemic. It can be concluded that the Faculty of 
Technical Sciences has readily welcomed online classes, because for many years students have the opportunity to use online platforms (moodle ellab platform) and teachers were mostly trained to work on it, so with less extra effort the faculty had switched entirely to online teaching and successfully responded to the emergency situation in which higher education unfortunately found itself.

Education systems will still have to meet several preconditions for quality education, namely: (1) access to information and communication technologies (ICT) and the Internet; (2) the availability of quality content on the Internet; (3) teachers with distance and online teaching skills; (4) parental support for distance and online teaching; and (5) a sufficient number of teaching hours (Burzanovic, 2020). Improved distance learning organization and support for teachers and students, pupils as well as parents can reduce the loss of learning in the future. Learning programs that can compensate for the loss of learning, as well as education budgets that provide a minimum of compensation for additional costs that may occur after the end of the COVID-19 pandemic, are crucial to enable students to make up for lost time growth of inequality.

It is necessary in the period of recovery of education from the pandemic, to continue teaching at a distance, but now also in classrooms in smaller groups, and to mitigate the loss of learning as equally as possible. Students from poorer backgrounds have more limited access to the Internet and computers at home, and thus fewer opportunities for interactive learning. To prevent worsening inequalities and reduce the risk of dropping out, states could consider providing access to the Internet and digital devices for these students, which has already been done at the Faculty of Engineering during the pandemic where courses are open for each subject and in the course, each student received an agreed number of gigabytes so that he/she could receive learning material and video from lectures and exercises, and follow the content of the faculty online at no additional cost (Burzanovic, 2020).

Countries are definitely changing exam formats in some way. Although a number of options can be considered, it is important to ensure that each solution is specifically tailored to the circumstances in a particular country and that the purpose of the exam is taken into account. The transition from one level to another will require greater support for learning during the next school year, the organization of summer schools or other forms of support to make up for missed material. It is also necessary to provide sufficient financial resources to be able to meet the need to compensate for the loss of learning, especially for vulnerable students, now that the faculties are partially reopened. The countries of the Western Balkans should also take this opportunity to make education more effective, inclusive and resilient. Improving and increasing the scope of successful policies introduced in response to COVID-19, such as reducing the digital division and improving teachers' digital skills, would make the system more resilient to future shocks, as well as dropping out fewer students (Burzanovic, 2020). 


\section{Conclusion}

The method of data collection and research via the Internet concludes that the technology and improvement of the education system provides the opportunity to improve online learning only and exclusively through adequate training of teaching staff, and interactive textbooks and open educational content are strategically linked to educational institutions.

The question is what education will look like in the future, is the advantage of online education recognized and did we understand through the pandemic that we can function differently when it comes to lectures at colleges in particular? Online teaching really reduces the cost of schooling and leaves more time for some other activities. As the costs of traditional education rise, online learning is experiencing its expansion, as it represents savings in both money and time, as everything can function from home. The increasing use of online teaching creates the need to eventually open distance learning centers that would operate at colleges, but intended for this form of education. Online education has proven itself (during the pandemic) through a multitude of digital platforms as a form of education that makes it easier for teachers to pass on teaching materials to students by enabling them to see their students during work, interact with them and receive instant feedback, lectures. They can also work in peace with less successful students in private conversation and provide them with the extra support they need, which would be impossible in a noisy classroom. Although as a result of online schooling we have a drastic reduction in costs in terms of transport, travel, and therefore schooling, this raises some other questions and some new topics in terms of socialization and how much the students will actually miss it if they completely switch to online education.

However, learning via electronic devices and digital platforms has somehow proved to be an unequal solution because only $60 \%$ of the population had access to the internet at the time of the pandemic, and a large percentage of the population is not information literate, and as such cannot provide adequate support to their children, as well as because of professional reasons (e.g. a nurse) - some people do not have time to help children with school activities. Another negative aspect of distance education is the insignificant number of students, especially lower school classes, who are not independent in learning, so the problem is in organizing their time, and if they do not have enough motivation, they will not be as successful as their peers (.NG, 2002).

On the other hand, there is a practice in foreign educational institutions that proves that the importance of distance learning is extremely great, especially for those who, due to some other obligations (e.g. work), cannot fully dedicate themselves to the classical way of schooling. However, according to experts, children must be in school, because all secondary socialization goes through school, without it we would raise generations of lonely children which is not good at all, and yet the question arises how many responsible seven-year-olds or 
teenagers would really sit alone in front of a computer for hours unsupervised, with school programs on the screen, except of course and only in the field of university education, where we can conditionally talk about some kind of chance when it comes to online education.

The current pandemic has caused unexpected, rapid, unequal changes in the education system and all participants in this system should have a common goal in overcoming the crisis, by finding the best possible solution when it comes to education, and in relation to the needs of the individual, especially if we are talking about higher education institutions. The traditional way of learning is not practical and adaptable to all conditions, and the online way of learning also has drawbacks, so that the ideal way of teaching in a longer period is a traditional way combined with online teaching that is advanced by modern technology, because together we can achieve the best results and a fairly ideal way of educating in the 21 st century as well.

The imperative of education is changing. It is clear that this pandemic has ultimately disrupted the education system, which many claim has already lost in importance. In his book "21 Lessons for the 21st Century" (Harari, 2018) points out that schools continue to focus on teaching traditional academic skills, rather than skills such as critical thinking or adaptability skills, which will be more important for future success. While some worry that the accelerated transition to e-learning could jeopardize the creation of new, more effective methods of educating students, others plan to make e-learning their "new normal" after experiencing first-hand benefits. During this pandemic, it is important to spread knowledge among countries, companies and all parts of society. If online learning technology can contribute to this, it is up to all of us to explore its full potential but also to help each other (student helps professors with feedback as well as professors help students) to more easily adapt to new ways of acquiring knowledge combined with traditional lectures and with exercises we get the most out of it, achieving only better results in the following period.

\section{References}

Bao, W. (2020). COVID -19 and online teaching in higher education: A case study of Peking University. Human Behavior and Emerging Technologies, 2(2), pp. 113-115.

Burzanović, T. (2020). Ekonomski i socijalni uticaj COVID- 19, obrazovanje, Available

from: http://pubdocs.worldbank.org/en/687451590708742492/WBRER17-04-

Education-BOS.pdf Accessed: 2020-10-14

Choi, B.; Jegatheeswaran, L.; Minocha, A.; Alhilani, M.; Nakhoul, M. \& Mutengesa, E. (2020). The impact of the COVID-19 pandemic on final year medical students in the United Kingdom: a national survey. BMC Medical Education, 20(1), pp. 1-11. 
Demuyakor, J. (2020). Coronavirus (COVID-19) and Online Learning in Higher Institutions of Education: A Survey of the Perceptions of Ghanaian International Students in China. Online Journal of Communication and Media Technologies, 10(3), pp. 1-9.

Hewit, R. (2020). Students' views on the impact of Coronavirus on their highereducation experience. High education policy institute, Available from: https://www.hepi.ac.uk Accessed on: 2020-07-16

Lokanath, M.; Tushar, G. \& Abha, S. (2020). Online Teaching-Learning in Higher Education during Lockdown Period of COVID-19 Pandemic, International Journal of Educational Research Open, Available online 10 September 2020

Mulyanti, B.; Purnama, W. \& Pawinanto, R. (2020). Distance Learning in Vocational High Schools during the COVID-19 Pandemic in West Java Province, Indonesia. Indonesian Journal of Science and Technology, 5(2), 271-282.

Nambiar, D.(2020). The impact of online learning during COVID-19: students' and teachers' perspective. International Journal of Indian Psychology, 8(2), pp.783-793.

Nanigopal, K..; Pintu, P.; Avijit, R.; Jay, S.; Ankita, Z.; Rahul, M.; Bikash, B.; Prabir, D. \& Pradip, C. (2020) . Impact of lockdown on learning status of undergraduate and postgraduate students during COVID-19 pandemic in West Bengal, India. Children and Youth Services Review, pp.1-25.

Nemet, S.; Ostojic, G.; Kukolj, D.; Stankovski, S.; \& Jovanovic, D. (2019). Feature Selection Using Combined Particle Swarm Optimization and Artificial Neural Network Approach, Journal of Mechatronics, Automation and Identification Technology, Vol. 4, No. 4, 2019, pp. 7-11, ISSN 2466-3603

Paunović, P. (2020). Prisilna digitalizacija srpskog obrazovanja - kako je izgledalo preokretanje ogromnog sistema za samo nekoliko dana?, Available from: https://startit.rs/prisilna-digitalizacija-srpskog-obrazovanja-kako-jeizgledalo-preokretanje-ogromnog-sistema-za-samo-nekoliko-dana/ Accessed: 2020-10-14.

Quacquarelli, S. (2020). The Impact of the Coronavirus on Global Higher Education, Available from: https://www.qs.com, Accessed on: 2020-07-16.

Saif Almuraqab, N. A. (2020). Shall Universities at the UAE Continue Distance Learning After the COVID-19 Pandemic? Revealing Students' Perspective. International Journal of Advanced Research in Engineering and Technology (IJARET), 11(5), pp. 226-233.

Stankovski, S.; Ostojić, G.; Zhang, X.; Baranovski, I.; Tegeltija, S. \& Horvat, S. (2019). Mechatronics, Identification Tehnology, Industry 4.0 and Education, Proceedings of the 18th INFOTEH-JAHORINA 2019, Ljuboje Z. (Ed.), IEEE, East Sarajevo, Bosnia and Herzegovina.

Stankovski, S.; Ostojić, G. \& Zhang, X. (2016). Influence of Industrial Internet of Things on Mechatronics, Journal of Mechatronics, Automation and Identification Technology, Vol. 1, No. 1, March 2016, pp. 1-6, ISSN 2466-3603 
Tapper, J.; Batty, D. \& Savage M. (2020). Medical students take final exams online for first time, despite student concern. The Guardian, Available from: https://www.theguardian.com/education/2020/mar/22/coronavirus-forcesmedical-students-sit-final-exams-online Accessed: 2020-06- 20 Wang, C. \& Zhao, H. (2020). The Impact of COVID-19 on Anxiety in Chinese University Students. Frontiers in Psychology, 11:1168, pp.1-8.

***GOV.RS Homepage, https://pametnoibezbedno.gov.rs/files/file_upload/fajl/ 9160_Pandemija_virusa_COVID_prevod.pdf Accessed: 2020-10-14 ***RTS Homepage, https://www.rts.rs/page/stories/sr Accessed: 2020-07-16 ***Novakdjokovicfoundation Homepage, https://novakdjokovicfoundation.org/ sr/uticaj-novih-tehnologija-na-obrazovanje/ Accessed: 2020-07-16

***ISERBIA Homepage, https://www.iserbia.rs/novosti/prednosti-i-nedostaciobrazovanja-putem-interneta-2804 Accessed: 2020-07-16

***Danas Homepage, https://www.danas.rs/drustvo/onlajn-nastava-nijekacenje-predavanja-na-internet/ Accessed: 2020-07-20

***NG Hompage, https://www.nationalgeographic.rs/reportaze/clanci/12412znate-li-kojih-11-drzava-je-u-samom-vrhu-po-kvalitetu-obrazovanja.html Accessed: 2020-07-20 